SOCIAL HISTORIES OF MEDICINE

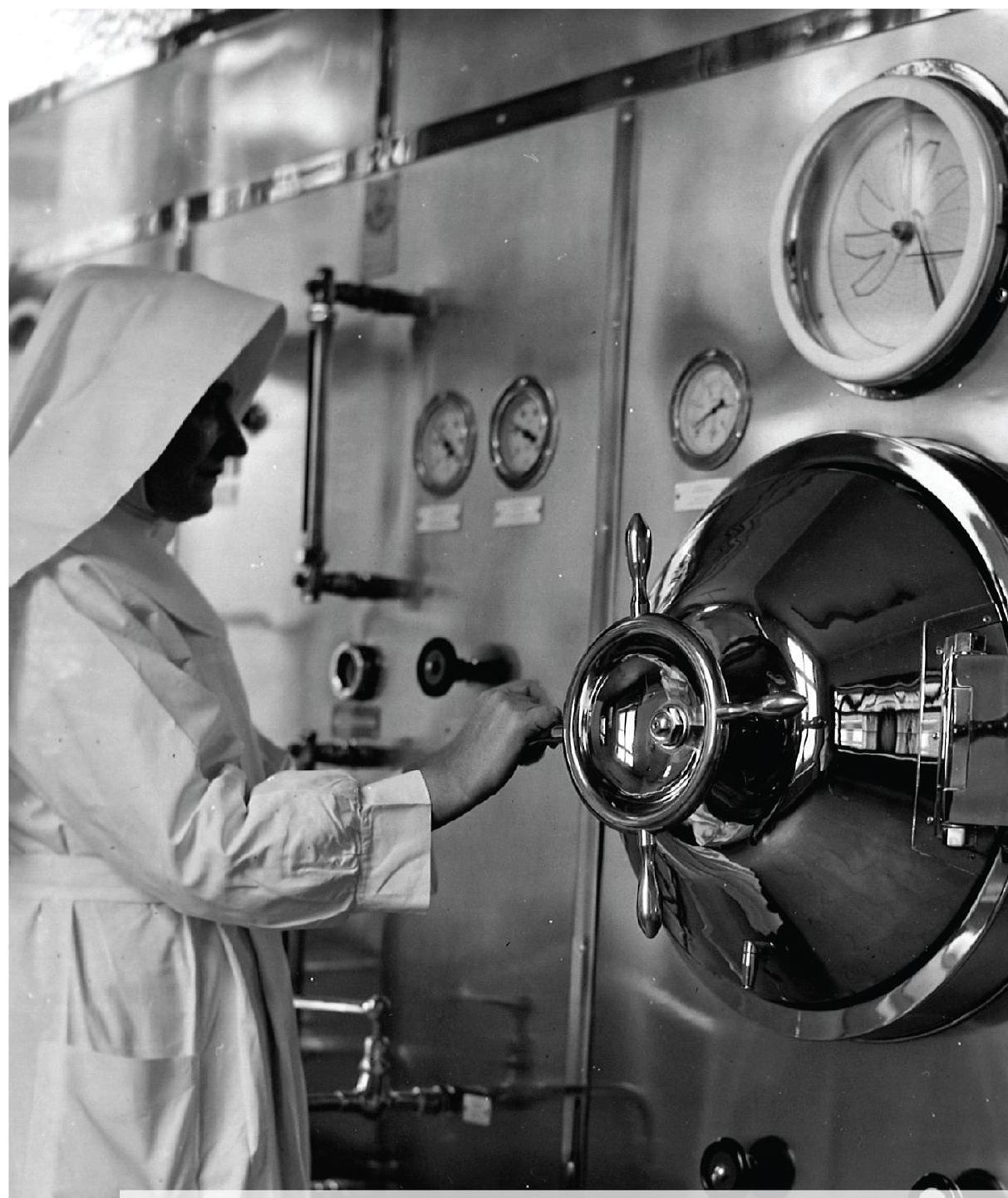

Edited by Joris Vandendriessche and Benoît Majerus Medical histories
of Belgium

New narratives on health, care and citizenship in the nineteenth and twentieth centuries 
Medical histories of Belgium

\section{MANCHESTER 1824}

Manchester University Press 


\section{SSH}

\section{SOCIAL HISTORIES OF MEDICINE}

\section{Series editors: David Cantor, Elaine Leong and Keir Waddington}

Social Histories of Medicine is concerned with all aspects of health, illness and medicine, from prehistory to the present, in every part of the world. The series covers the circumstances that promote health or illness, the ways in which people experience and explain such conditions and what, practically, they do about them. Practitioners of all approaches to health and healing come within its scope, as do their ideas, beliefs and practices, and the social, economic and cultural contexts in which they operate. Methodologically, the series welcomes relevant studies in social, economic, cultural and intellectual history, as well as approaches derived from other disciplines in the arts, sciences, social sciences and humanities. The series is a collaboration between Manchester University Press and the Society for the Social History of Medicine.

\section{Previously published}

Migrant architects of the NHS Julian M. Simpson

Mediterranean quarantines, 1750-1914 Edited by John Chircop

and Francisco Javier Martínez

Sickness, medical welfare and the English poor, 1750-1834 Steven King

Medical societies and scientific culture in nineteenth-century Belgium

Joris Vandendriessche

Vaccinating Britain Gareth Millward

Madness on trial James E. Moran

Early modern Ireland and the world of medicine Edited by John Cunningham

Feeling the strain Jill Kirby

Rhinoplasty and the nose in early modern British medicine and culture

Emily Cock

Communicating the history of medicine Edited by Solveig Jülich and Sven Widmalm

Progress and pathology Edited by Melissa Dickson, Emilie

Taylor-Brown and Sally Shuttleworth

Balancing the self Edited by Mark Jackson and Martin D. Moore

Global health and the new world order Edited by Jean-Paul Gaudillière,

Claire Beaudevin, Christoph Gradmann, Anne M. Lovell and Laurent Pordié

Accounting for health: calculation, paperwork and medicine, 1500-2000

Edited by Axel C. Hüntelmann and Oliver Falk

Women's medicine Caroline Rusterholz

Germs and governance: the past, present and future of hospital infection, prevention and control Edited by Anne Marie Rafferty, Marguerite Dupree and Fay Bound Alberti

Leprosy and identity in the Middle Ages: from England to the Mediterranean Edited by Elma Brenner and François-Olivier Touati 


\title{
Medical histories of Belgium
}

New narratives on health, care and citizenship in the nineteenth and twentieth centuries

\author{
Edited by \\ Joris Vandendriessche and Benoît Majerus
}

Manchester University Press 
Copyright ( 9 Manchester University Press 2021

While copyright in the volume as a whole is vested in Manchester University Press, copyright in individual chapters belongs to their respective authors.

An electronic version of this book is also available under a Creative Commons (CC-BY-NC-ND) licence, thanks to the support of the University of Luxembourg, which permits non-commercial use, distribution and reproduction provided the editor(s), chapter author(s) and Manchester University Press are fully cited and no modifications or adaptations are made. Details of the licence can be viewed at https:// creativecommons.org/licenses/by-nc-nd/4.0/

Published by Manchester University Press

Oxford Road, Manchester M13 9PL

www.manchesteruniversitypress.co.uk

British Library Cataloguing-in-Publication Data

A catalogue record for this book is available from the British Library

ISBN 9781526151087 hardback

First published 2021

The publisher has no responsibility for the persistence or accuracy of URLs for any external or third-party internet websites referred to in this book, and does not guarantee that any content on such websites is, or will remain, accurate or appropriate.

Cover image: A woman religious operating sterilisation equipment in the Leuven academic hospitals. Heritage Centre I Sisters of Charity J. M.

Cover design: riverdesignbooks.com

Typeset by Newgen Publishing UK 